\title{
Neuropharmacological properties of Launaea resedifolia
}

\author{
Abdu Razag A. Auzi ${ }^{1}$, Najat T. Hawisa ${ }^{2}$, Fathi M. Sherif ${ }^{2}$, Satyajit D. Sarker ${ }^{3 *}$ \\ ${ }^{1}$ Pharmacognosy Department, Faculty of Pharmacy, Elfateh University, Tripoli, Libya, \\ ${ }^{2}$ Pharmacology Department, Faculty of Pharmacy, Elfateh University, Tripoli, Libya, \\ ${ }^{3}$ School of Biomedical Sciences, University of Ulster at Coleraine, Cromore Road, \\ Coleraine BT52 1SA, Co. Londonderry, Northern Ireland, UK
}

\begin{abstract}
RESUMO: “Propriedades neurofarmacológicas de Launaea resedifolia”. Launaea resedifolia (L.) Kuntze (família: Asteraceae), sinônimo Scorzonera resedifolia L., é uma planta medicinal utilizada na medicina popular da Líbia para o tratamento de problemas hepáticos. Todavia, não há relato de qualquer avaliação farmacológica de L . resedifolia disponível na literatura. Neste estudo, o potencial neurofarmacológico do extrato etanólico desta planta foi analisado em modelos animais. Os extratos de Launaea resedifolia exibiram um efeito inibitório na atividade locomotora de camundongos no teste de campo aberto, um efeito anti-nociceptivo pelo aumento do tempo de reação em placa quente no teste da placa quente e uma atividade anti-inflamatória no edema de pata induzido por carragenina. Além disso, um efeito sedativo foi evidente pela diminuição no início do tempo de sono barbitúrico e aumento na duração do tempo de sono barbitúrico em ratos. O extrato etanólico também demonstrou uma diminuição significativa na taxa de mortalidade induzida por picrotoxina em aproximadamente 66\% e uma redução considerável no peso corporal de camundongos comparada aos grupos controle.
\end{abstract}

Unitermos: Launaea resedifolia, Asteraceae, propriedade neurofarmacológica.

\begin{abstract}
Launaea resedifolia (L.) Kuntze (family: Asteraceae), synonym Scorzonera resedifolia $\mathrm{L}$., is a medicinal plant used in the Libyan folkloric medicine mainly for the treatment of hepatic pains. However, there is no report on any pharmacological evaluation of $L$. resedifolia available to date. In this study, the neuropharmacological potential of the ethanol extract of this plant has been assessed in animal models. Launaea resedifolia extracts exhibited an inhibitory effect on the locomotor activity of mice in the open field test, an anti-nociceptive effect by increasing the hot plate reaction time in the hot plate test, and an anti-inflammatory activity in the carrageenaninduced paw oedema. Furthermore, a sedative effect was evident from the decrease in the onset of pentobarbitone sleeping time and increase in the duration of pentobarbitone sleeping time rats. The ethanol extract also demonstrated a significant decrease in the mortality rate induced by picrotoxin by about $66 \%$, and a considerable reduction in the body weight of mice compared to the control groups.
\end{abstract}

Keywords: Launaea resedifolia, Asteraceae, neuropharmacological property.

\section{INTRODUCTION}

Launaea resedifolia (L.) Kuntze (tribe: Lavtuceae; family: Asteraceae alt. Compositae), synonym Scorzonera resedifolia L., is a medicinal plant used in the Libyan folkloric medicine mainly for the treatment of hepatic pains (Qureshi et al., 2002; EL-Gady; ElMograby, 1999). This perennial stoloniferous herb (up to $40 \mathrm{~cm}$ tall) is widely distributed in the wetland of the arid regions of the Mediterranean, and also found in many other countries, e.g. Algeria, Libya, Tunisia, Pakistan and India. While there is no report on any systematic pharmacological evaluation of $L$. resedifoilia available to date, previous phytochemical studies revealed the presence of phenolic compounds, e.g. flavonoids, coumarins and phenolic acids, in this plant (Giner et al., 1992; Gherraf et al., 2006). We now report on the neuropharmacological properties of the ethanol extract of L. resedifolia in animal models.

\section{MATERIAL AND METHODS}

\section{Plant material}

Launaea resedifolia (L.) Kuntze was collected from Aljabal Algharby, Libya, during May 2004, and was authenticated in the herbarium at the Department of Botany, Faculty of Science, Elfateh University, Tripoli, Libya, where a voucher specimen for this collection (HLR4-2004) has been maintained.

\section{Preparation of plant extracts}


Shade-dried and powdered aerial parts of $L$. resedifolia were extracted by maceration $(72 \mathrm{~h}$, with occasional shaking) using ethanol at room temperature. The procedure was repeated three times with fresh solvent. The pooled extracts were filtered, and concentrated using a rotary evaporator at $60{ }^{\circ} \mathrm{C}$ under reduced pressure using a vacuum pump, and then air-dried and kept in dark coloured glass container.

\section{Chemicals}

Carrageenan powder, ethanol (95\% w/v), glacial acetic acid, gum acacia, normal saline, pentobarbitone sodium, phenobarbitone sodium and picrotoxin powder were of chemical grade and obtained from various commercial suppliers.

\section{Animals}

Albino Wistar rats weighing $160 \pm 30 \mathrm{~g}$ and albino mice weighing $22 \pm 2 \mathrm{~g}$ of both sexes were used throughout the study. Unisex animals were used in the same experiment for the test and the control groups in order to reduce the biological variations. The animals were obtained from local animal house (Faculty of Pharmacy, ElFateh University, Tripoli, Libya). The animals were kept in specific cages (6 animals in each cage), food (composed of cereals, beans and corn) and tap water were available ad lib. The animals were kept in a room temperature varying between 20 to $25^{\circ} \mathrm{C}$, with $12 \mathrm{~h}$ dark/light cycle and were overnight fastened before each experiment unless stated otherwise.

\section{Acute toxicity assay}

Different doses of the plant extract (200, 400, 800 and $1200 \mathrm{mg} / \mathrm{kg}$ body weight) suspended in $1 \%$ gum acacia were administered to mice. Each dose of plant extract was given orally to a group of overnight fastened mice consists of six animals $(n=6)$. The mice were observed for $2 \mathrm{~h}$ after oral feeding with the extract for any abnormal changes in behaviour and for the mortality rate for $72 \mathrm{~h}$ post-administration of the plant extract.

\section{Effect on the general locomotor activity}

The open field test (Sahgal, 1993) for locomotor activity of mice was performed in a closed square arena (60 x $60 \mathrm{~cm}$ ) with a $30 \mathrm{~cm}$ height made of fibre-glass. The arena was divided into 16 equal squares. The exploratory behaviour in the open field was observed in a calm room under a low level of illumination (not more than $20 \mathrm{~W}$ ) between 9:00 am and 1:00 pm in February under similar conditions of temperature, humidity and natural dark/ light cycle. The animal was placed at the centre of the open field arena and observed for $4 \mathrm{~min}$. The parameters measured were the horizontal and vertical movements.
Thus, the number of squares visited in the central and peripheral areas (with both fore and hind paws on a square) and the number of rears were recorded. Two groups of animals ( $\mathrm{n}=6$ for each group) were used in this experiment. The test was carried out $1 \mathrm{~h}$ after oral administration of $L$. resedifolia extract (LRE), at a dose of $400 \mathrm{mg}$ per $\mathrm{kg}$ body weight, to the first group and the vehicle ( $1 \%$ gum acacia) to the second group that served as a control. A similar test was carried out using another two groups of mice ( $\mathrm{n}=6$ for each group) after repeated oral administration of $50 \mathrm{mg}$ per $\mathrm{kg}$ of LRE to the first group and the vehicle to the second group am for 21 days between 9:00 - 10:00. The test was carried out after one week, two weeks and three weeks of repeated treatment with the plant extract and the vehicle.

\section{Hot-plate test}

According to Eddy's method (Eddy et al., 1950), each mouse was placed individually on a hot plate (55 \pm $0.5^{\circ} \mathrm{C}$ ) until the response to thermal pain was observed. The reaction time was taken when they licked their paws, squeaked and tried to escape within few seconds. The time taken for each mouse to respond was recorded as a cut off time. Mice were not allowed to remain on the hot plate for more than 25 seconds in order to avoid burn injury. Animals not responding within this period can be considered protected. Twenty overnight-fastened mice, randomly divided into four groups ( $\mathrm{n}=5$ for each group) were used in this experiment. Each group was given a certain dose of the test extract (200, 400 or $800 \mathrm{mg} / \mathrm{kg}$, p.o.) and one group was given the vehicle (1\% gum acacia, p.o.) and served as a control (Turner; Hebborn, 1971). The test was carried out 30, 60 and 120 minutes after administration of the plant extract.

\section{Anti-inflammatory effect using carrageenan-induced paw oedema in mice}

Four groups of male albino mice weighing 22 $\pm 2 \mathrm{~g}(\mathrm{n}=6)$ were used in this experiment. One group had received LRE orally at a dose of $400 \mathrm{mg} / \mathrm{kg}$ body weight, the second group received aspirin orally at a dose of $100 \mathrm{mg} / \mathrm{kg}$ body weight, the third group received a combination of LRE $(400 \mathrm{mg} / \mathrm{kg}$ ) and aspirin $(100 \mathrm{mg} / \mathrm{kg})$, and the last group received the vehicle which served as a control. After $1 \mathrm{~h}, 0.025 \mathrm{~mL}$ of $1 \%$ carrageenan solution was injected subcutaneously into one hind paw of each mouse. Three hours later, the thickness of each hind paw of each animal in all the groups was measured by means of a micrometer. The difference in thickness between the two paws indicates the amount of oedema developed in each mouse. The mean difference of each test group was calculated and compared with the mean difference of the control group and percentage of inhibition caused by the test extract was calculated by: \% Inhibition $=100-(\mathrm{T} / \mathrm{C} \mathrm{x}$ 100). Where $T$ and $C$ are the mean difference in oedema 
formation for treated and control groups respectively (Dhawan; Srimal, 1997).

\section{Hypnotic effect (potentiation of barbiturate hypnosis)}

Two groups of female albino Winstar rats (each consists of six) weighing $130 \pm 30$ g were used in this experiment. The first group was given LRE orally at a dose of $400 \mathrm{mg} / \mathrm{kg}$ and the other group was given the vehicle to serve as a control group. One hour later each rat in the two groups was injected intraperitoneally (i.p.) with $20 \mathrm{mg} / \mathrm{kg}$ of pentobarbitone sodium. The onset and duration of the sleeping time (loss of righting reflex) of the animals were recorded for each group (Singh; Sanyal, 2003).

\section{Antagonism of chemically induced seizure (picrotoxin induced convulsion)}

Two groups of female albino mice weighing 20$24 \mathrm{~g}$ (each group consists of 6 animals) were used in this experiment. One group received LRE (400 mg/kg body weight p.o.) and the second group received the vehicle (1\% gum acacia) p.o., which served as a control. After $1 \mathrm{~h}$, a dose of $15 \mathrm{mg} / \mathrm{kg}$ body weight of picrotoxin was injected subcutaneously to each mouse in each group. The latency (onset of seizure induction), number of convulsions within a period of $30 \mathrm{~min}$, and death rate were recorded as a biological indicator (Floyd, 1971). Similar procedure was carried out using LRE (400 mg/ $\mathrm{kg}$ ) and picrotoxin (3.4 mg/kg body weight) (Klodzinska et al., 1999), and phenobarbitone sodium in a dose of 20 $\mathrm{mg} / \mathrm{kg}$ intraperitoneally (Ojewole, 2005) as a control. The above-mentioned parameters were recorded.

\section{Effect on body weight}

Two groups of female albino mice weighing 22 $\pm 2 \mathrm{~g}$ ( $\mathrm{n}=6$ for each group) were used in this experiment. The body weight of each animal was recorded daily for 21 days before oral administration of LRE $(50 \mathrm{mg} / \mathrm{kg}$ body weight) to the test group and the vehicle (1\% gum acacia) to the control group. The animals were allowed to have a free access of food and water. Data were tabulated and the mean daily body weight for each group versus the time was plotted.

\section{Statistical analysis}

Data composed of five animals in each group and unmatched data were analysed by Mann-Whitney $U$ test and were expressed as the median \pm S.D. Otherwise, data were analyzed by means of paired t test and were expressed as the means \pm S.E. $\mathrm{P}$ values $<0.05$ are considered statistically significant and $\mathrm{P}$ values $<0.01$ are considered highly significant. To estimate whether the data are parametric or non parametric, the date were analysed by Kolmogorov-Smirnov test using SPSS program (Puri, 1996).

\section{RESULTS AND DISCUSSION}

Launaea resedifolia is a Libyan medicinal plant used traditionally as a painkiller for hepatic pain, and it is widely distributed all-over Libya (EL-Gady; El-Mograby, 1999). In the present study, the administration of $L$. resedifolia extract (LRE) at different doses (200 - 1200 mg per kg, p.o.) to male adult albino mice did not show any abnormal sign or bizarre behaviour, except a slight decrease in the general motor activity of the animals when observed for $2 \mathrm{~h}$ (Irwin primary screening test, data are not shown). On the other hand, there were no mortality cases during the 72 hours of the experiment. Thus, the approximate $\mathrm{LD}_{50}$ was roughly estimated as $1200 \mathrm{mg}$ per $\mathrm{kg}$, similar to the value previously described by Dhawan and Srimal (1997).

The general locomotor activity and the exploratory behaviour were assessed by the open field model of exploratory behaviour after a single dose (400 mg/kg, p.o.), and after a repeated treatment with a small dose of the plant extract $(50 \mathrm{mg} / \mathrm{kg}$, p.o.) for three weeks (Table 1). The parameters measured were the ambulatory activities represented by the horizontal movements (number of squares crossed by the mouse in the central and the peripheral areas) and the exploratory activity represented by the vertical movement (number of rears in the central and the peripheral areas). Statistical analysis of the data have revealed significant decrease ( $P$ $<0.05)$ in the horizontal movement in the peripheral area and in the total horizontal movement within the group treated with LRE (400 mg/kg, p.o.) compared to that of the control group (Table 1). In the open field test for locomotor activity, analysis of the data by paired t-Test revealed that there was a statistically significant reduction in the ambulatory movement (represented by the horizontal movements) without any significant changes in the exploratory movement (represented by the vertical movements or rearing) of mice after two and three weeks of repeated treatment of mice with LRE (at $P<0.05$ and at $P<0.01$ ) compared with the control group (Tables 1 ). Thus LRE exhibited significant decrease in the locomotor activity of the animals after acute treatment. These results indicate that LRE produced an inhibitory effect on the ambulatory behaviour and hence reduced the motor activity without affecting the exploratory behaviour (Sahgal, 1993).

Antinociceptive effect of LRE was investigated by the standard Eddy's hot plate method as a thermal pain experimental model (Turner; Hebborn, 1971). Administration of LRE in single doses of 200, 400 and $800 \mathrm{mg}$ per kg of body weight, p.o., showed an increase in the hot plate reaction time by $20 \%$ to $65 \%$ of the control value (Table 2). Analysis of the data by the Mann-Whitney 
$U$ test revealed a statistically significant difference in the hot plate reaction time between the test and the control group $(P<0.05-0.01)$. Thus LRE exhibited a significant analgesic effect at the doses studied after one and two hours of administration. This analgesic action and its antinociceptive activity might be centrally mediated.

The anti-inflammatory effect of LRE was investigated in mice by the carrageenan-induced paw oedema method (Dhawan; Srimal, 1997) using aspirin (100 mg per kg, p.o.) as a reference compound. Analysis of the data has revealed a profound anti-inflammatory effect both for LRE (400 mg per kg, p.o.), aspirin (100 mg per kg, p.o.) and for the mixture of LRE and aspirin (Table 3). Percentage of inhibition of the oedema was about $70 \%$ for LRE, $70 \%$ for aspirin and $90 \%$ for the combined mixture. The mechanism of the observed antiinflammatory effect of LRE could be through inhibition of prostaglandins, since prostaglandins probably exert their pro-inflammatory effects in the late phases of inflammation (2.5-6 h). It is well known that carrageenaninduced inflammatory reaction has two phases: early and late phases. The early phase lasts for $60 \mathrm{~min}$ and is associated with release of autacoids such as histamine, serotonin and bradykinin. The late phase occurs within 60 min after injection and lasts for three hours. This phase is associated with neutrophil-originated free radicals, such as hydrogen peroxide, superoxide and hydroxyl radicals, as well as prostaglandin release (Süleyman et al., 2004). However, our measurement was taken three hours after carrageenan injection.

Potentiation of barbiturate action was investigated in female albino Wistar rats, where pentobarbitone sodium was given to rats pre-treated with LRE (Table 4). Analysis of the data by the Mann-Whitney $\mathrm{U}$ test revealed a statistically significant difference $(P<$ $0.05)$ in the duration of pentobarbitone sleeping time and a highly significant difference $(P<0.01)$ in the onset of pentobarbitone sleeping time between the group treated with LRE and the control group. This finding suggested that LRE could prolong the sleeping time produced by pentobarbitone and hence it might have effects on the central nervous system represented by a sedative or hypnotic effect, or LRE might have an inhibitory effect on pentobarbitone metabolism. Taking together the above results (motor activity and hypnotic studies), it can be assumed that the plant extract could have a potential use as sedative or hypnotic agent. This effect might be mediated via GABA system.

A comparison between the anticonvulsant effect of LRE and phenobarbitone was carried out by using picrotoxin, a proconvulsive agent, at a dose of $3.4 \mathrm{mg} / \mathrm{kg}$ (Klodzinska et al., 1999). Phenobarbitone sodium was used as a positive control. Latency of seizure, number of convulsions and mortality rate were recorded. There was a reduction in the mortality rate within the group treated with LRE by about $67 \%$. Analysis of the data by the Mann-Whitney $U$ test has indicated statistically insignificant difference between the group treated with Launaea resedifolia extract and the control group (Table 5). On the other hand, there was a complete protection within the group treated with phenobarbitone sodium (survival rate 100\%). However, the difference in the onset and number of convulsions between the test group and the control group was statistically insignificant. These findings, however, do not assert that the plant extract had no anticonvulsant activity when tested with other methods of inducing convulsion e.g. electroconvulsive method or by using other proconvulsant chemicals like strychnine or PTZ.

In Table 6, the average of the daily measured body weights of the treated and control groups are tabulated and plotted against time. It was observed that LRE caused a steady decline of body weight by time in comparison with the control. Statistical analysis of the data have revealed a significant decrease in body weight at $P<0.05$ within the group treated with LRE after 3

Table 1. Effect of Launaea resedifolia extract (LRE) on the general locomotor activity in mice (single treatment and repeated daily treatment).

\begin{tabular}{|c|c|c|c|c|c|c|c|c|c|}
\hline \multirow{4}{*}{\multicolumn{2}{|c|}{ Type of movements }} & \multicolumn{8}{|c|}{ Treatment } \\
\hline & & \multirow{2}{*}{\multicolumn{2}{|c|}{$\begin{array}{c}\text { Single application } \\
\text { After } 1 \mathrm{~h}\end{array}$}} & \multicolumn{6}{|c|}{ Repeated daily treatment } \\
\hline & & & & \multicolumn{2}{|c|}{ After 1 week** } & \multicolumn{2}{|c|}{ After 2 weeks } & \multicolumn{2}{|c|}{ After 3 weeks } \\
\hline & & Control & $\mathrm{LRE}^{\mathrm{a}}$ & Control & $\mathrm{LRE}^{\mathrm{b}}$ & Control & $\mathrm{LRE}^{\mathrm{b}}$ & Control & $\mathrm{LRE}^{\mathrm{b}}$ \\
\hline \multirow[t]{3}{*}{ Horizontal } & Central & $09.33 \pm 1.82$ & $05.17 \pm 0.54$ & $10.00 \pm 2.62$ & $05.17 \pm 02.50$ & $06.00 \pm 1.51$ & $02.50 \pm 1.15$ & $10.80 \pm 3.47$ & $02.00 \pm 0.32$ \\
\hline & Peripheral & $49.17 \pm 3.10$ & $35.00 \pm 4.23 *$ & $41.00 \pm 5.57$ & $46.17 \pm 08.55$ & $39.50 \pm 7.05$ & $18.67 \pm 6.35^{\S}$ & $45.40 \pm 6.23$ & $21.00 \pm 4.53^{\S}$ \\
\hline & Total & $58.50 \pm 4.39$ & $40.33 \pm 4.24^{*}$ & $51.00 \pm 7.37$ & $51.20 \pm 10.70$ & $45.50 \pm 8.47$ & $21.17 \pm 6.25^{\S}$ & $56.20 \pm 9.11$ & $23.00 \pm 4.74^{*}$ \\
\hline \multirow[t]{3}{*}{ Vertical } & Central & $00.66 \pm 0.49$ & $00.33 \pm 0.33$ & $1.16 \pm 0.650$ & $00.50 \pm 00.34$ & $00.00 \pm 0.00$ & $00.00 \pm 0.00$ & $01.20 \pm 0.97$ & $00.00 \pm 0.00$ \\
\hline & Peripheral & $14.33 \pm 2.97$ & $10.64 \pm 3.18$ & $13.83 \pm 2.96$ & $07.67 \pm 02.54$ & $09.33 \pm 3.72$ & $01.83 \pm 0.60$ & $10.60 \pm 4.25$ & $01.80 \pm 0.73$ \\
\hline & Total & $15.00 \pm 3.32$ & $09.33 \pm 2.19$ & $15.00 \pm 3.25$ & $08.17 \pm 02.86$ & $09.33 \pm 3.72$ & $01.83 \pm 0.60$ & $11.80 \pm 5.08$ & $01.80 \pm 0.73$ \\
\hline
\end{tabular}

Data shown are the means \pm S.E., $n=6$ for each group.

a $400 \mathrm{mg} / \mathrm{kg}$, p.o; $50 \mathrm{mg} / \mathrm{kg}$, p.o.

* $P<0.05$ by paired $\mathrm{t}$ test; ${ }^{* *}$ No significant difference by paired $\mathrm{t}$ test; ${ }^{\S} P<0.01$ by paired $\mathrm{t}$ test 
Table 2. Effect of Launaea resedifolia extract on thermal pain in albino mice.

\begin{tabular}{c|c|c|c}
\hline \multirow{2}{*}{ Doses in $\mathrm{mg} / \mathrm{kg}, \mathrm{p} . \mathrm{|}}$. & \multicolumn{3}{|c}{ Reaction time in sec } \\
\cline { 2 - 4 } & $\begin{array}{c}\text { After 30 min of } \\
\text { administration }\end{array}$ & $\begin{array}{c}\text { After 60 min of } \\
\text { administration }\end{array}$ & $\begin{array}{c}\text { After 120 min of } \\
\text { administration }\end{array}$ \\
\hline 200 & $10.6 \pm 1.53^{* *}$ & $10.0 \pm 3.31^{* *}$ & $13.1 \pm 5.02^{* *}$ \\
\hline 400 & $9.3 \pm 1.99^{*} 0$ & $10.2 \pm 1.47^{* *}$ & $13.0 \pm 3.32^{* *}$ \\
\hline 800 & $09.1 \pm 3.31$ & $10.2 \pm 3.79^{*}$ & $09.6 \pm 5.75^{*}$ \\
\hline
\end{tabular}

Data shown are the median \pm S.D., $\mathrm{n}=5$ for each test group.

$* P<0.05$ and $* * P<0.01$ by Mann-Whitney $U$ test in comparison with the control group

$(07.8 \pm 1.03, \mathrm{n}=15)$

Table 3. Anti-inflammatory effect of Launaea resedifolia (LRE) and aspirin in mice.

\begin{tabular}{l|l}
\hline Treatment & $\begin{array}{l}\text { Oedema in mm } \\
\text { (difference in paw thickness) }\end{array}$ \\
\hline Control & $1.04 \pm 0.43(00.00 \%)$ \\
LRE & $0.30 \pm 0.19^{*}(72.00 \%)$ \\
Aspirin & $0.41 \pm 0.13^{*}(69.49 \%)$ \\
LRE + Aspirin & $0.17 \pm 0.25^{* *}(87.00 \%)$ \\
\hline
\end{tabular}

Data given are the median \pm S.D., $\mathrm{n}=6$ for each group.

${ }^{*} P<0.05$ and ${ }^{* *} P<0.01$ by the Mann-Whitney $U$ test.

$L$. resedifolia: $400 \mathrm{mg} / \mathrm{kg}$, p.o; Aspirin: $100 \mathrm{mg} / \mathrm{kg}$, p.o.

Values between parentheses are the percentage of inhibition of the pedal oedema.

Table 4. Effect of Launaea resedifolia on pentobarbitone hypnosis in rats.

\begin{tabular}{l|l|l}
\hline Treatment & Onset (min.) & Duration (min.) \\
\hline Control & $8.00 \pm 0.63$ & $34.33 \pm 22.10$ \\
Launaea resedifolia $^{a}$ & $4.50 \pm 0.98^{* *}$ & $74.50 \pm 29.94^{*}$ \\
\hline
\end{tabular}

Data shown are the median \pm S.D., $\mathrm{n}=6$ for each group.

$* P<0.05$ and ${ }^{* *} P<0.01$ by the Mann-Whitney $U$ test.

a $400 \mathrm{mg} / \mathrm{kg}$, p.o.

Table 5. The protective effect of Launaea resedifolia and phenobarbitone against picrotoxin induced seizure.

\begin{tabular}{l|l|l|l}
\hline Treatment & Latency in min. & Number of convulsions & Mortality rate in 24 h \\
\hline Control & $14.50 \pm 4.67$ & $4.50 \pm 2.43$ & $50.00 \%$ \\
Launaea resedifolia $^{a}$ & $15.50 \pm 6.47$ & $3.50 \pm 2.66$ & $16.66 \%$ \\
Phenobarbitone $^{b}$ & $00.00 \pm 0.00$ & $0.00 \pm 0.00$ & $00.00 \%$ \\
\hline
\end{tabular}

Data shown are the Median \pm S.D., $n=6$ for each group.

No significant difference was found by Mann-Whitney $U$ test.

a $400 \mathrm{mg} / \mathrm{kg}$, p.o; ${ }^{\mathrm{b}} 20 \mathrm{mg} / \mathrm{kg}$, IP.

Table 6. Effect of repeated $L$. resedifolia intake on body weight.

\begin{tabular}{l|c|c|c|c}
\hline \multirow{2}{*}{ Treatment } & \multicolumn{4}{|c}{ Body weight in grams } \\
\cline { 2 - 5 } & At 0 time & After 1 week & After 2 weeks & After 3 weeks \\
\hline Control & $22.19 \pm 0.99$ & $22.72 \pm 0.64$ & $22.61 \pm 1.38$ & $22.25 \pm 1.70$ \\
\hline L. resedifolia $^{a}$ & $23.61 \pm 0.55$ & $22.75 \pm 0.80$ & $22.06 \pm 0.76$ & $20.74 \pm 0.67 *$ \\
\hline
\end{tabular}

Data shown are the Means \pm S.E., $n=6$ for each group.

$* p<0.05$ by the paired test.

${ }^{\mathrm{a}} \mathrm{L}$. resedifolia: $50 \mathrm{mg} / \mathrm{kg}$, p.o. 
weeks of treatment in comparison with the body weights Vol. II 231-232. Academic Press, New York, USA. of the same group at the beginning of the experiment (self control), while revealed insignificant change in body weights of the group treated with the vehicle.

The findings of the current study have demonstrated that the extract of $L$. resedifolia possesses sedative, analgesic and anti-inflammatory properties, and some effect on body weight. The anti-inflammatory effect of the plant was found to be as active as the prototype non-steroidal anti-inflammatory drug (NSAID) aspirin.

\section{ACKNOWLEDGEMENTS}

The authors would like to thank Dr. Fathi Rateeb for taxonomical identification and Mr Ali Elrabti for providing the plant material.

\section{REFERENCES}

Dhawan K, Srimal A 1997. Laboratory manual for pharmacological evaluation of natural products, ICS and UNIDO, Trieste, Italy.

Eddy NB, Touchberry CF, Liberman JE 1950. Synthetic analgesics methadone isomers and derivatives. $J$ Pharmacol Exp Ther 98: 121-137

EL-Gady AA, El-Mograby MA 1999. Usage of some plants in Libya folk-medicine. Part three, $1^{\text {st }}$ edn. Dar Al-hekma for printing and distribution and advertisement, Tripoli, Libya.

Floyd R 1971. Animal experiments in pharmacological analysis. Thomas, Springfield- Illinois USA.

Gherraf N, El-Bassuony AA, Zellagui A, Rhouati S, Ahmed AA, Quaharani MR 2006. Isolation of coumarins and coumarin glucosides from Launaea resedifolia. Asian J Chem 18: 2348-2352.

Giner RM, Diaz J, Manez S, Recio MC, Soriano C, Rios JL 1992. Phenolics of Spanish Launaea species. Biochem Syst Ecol 20: 187-188.

Klodzinska A, Chojnacka-Wojcik E, Pilc A 1999. Selective group II glutamate metabotropic receptor agonist LY354740 attenuate pentylenetetrazole and picrotoxin induced seizures. Pol J Pharnacol 51: 543-545.

Ojewole J 2005. Analgesic and anticonvulsant properties of Tetrapleura tetraptera fruit aqueous in mice. Phytother Res 19: 1023-1029.

Puri P 1996. Statistics for the health science using SPSS. Saunders Company Ltd., London, UK.

Qureshi SJ, Awan AG, Khan MA, Bano S 2002. Taxonomic study of the genus Launaea L. from Pakistan. Online Journal of Biological Sciences 2: 315-319.

Sahagal A 1993. Behavioural neuroscience. A practical approach. Vol. II. IRL Press at Oxford University Press, Sodertalj-Sweden.

Singh K, Sanyal A 2003. Effect of under nutrition on morphine analgesia, haloperidol catalepsy and pentobarbitone hypnosis in developing newborn rats. Indian $J$ Med Sci 57: 164-170.

Süleyman H, Demircan B, Karagoz Y, Ozatasan N, Süleyman B 2004. Anti-inflammatory effects of selective cox-2 inhibitors. Pol J Pharmacol 56: 775-780.

Turner R, Hebborn P 1971. Screening methods in pharmacology. 